\title{
A QUANTITATIVE STUDY OF THE DIGITOXIN CONTENT OF EDEMA FLUIDS ${ }^{1}$
}

\author{
By SHIRLEY ST. GEORGE, CHARLES F. NAEGELE, FRANK S. FRENCH, \\ RAY H. ROSENMAN, AND MEYER FRIEDMAN \\ (From the Harold Brunn Institute, Mount Zion Hospital, and the Medical Service, The \\ United States Public Health Service Hospital, San Francisco, Calif.)
}

(Submitted for publication June 22, 1953; accepted August 11, 1953)

For many years it has been suggested that considerable quantities of digitalis bodies accumulate in edema fluid, that rapid diuresis with mercurial diuretic drugs "liberates" these glycosides into the blood stream as the edema fluids are mobilized and excreted by the kidneys, and that the ensuing "redigitalization" may lead to manifestations of digitalis toxicity in the already adequately digitalized patient (1). A survey of the literature reveals that this belief is based largely upon clinical impressions rather than upon careful studies of the content of digitalis glycosides actually present in accumulations of edema fluid. The clinical importance of this problem led to the present investigation of the digitoxin content of edema fluids, utilizing microassay techniques now available.

\section{METHODS}

Peritoneal, pleural, and subcutaneous edema fluids were removed by paracentesis or through Southey tubes from seven patients with accumulations of edema fluid of hepatic or cardiac origin, and from one patient with pleural effusion secondary to a lymphoma. In six patients fluid was collected prior to the oral administration of $1.2 \mathrm{mg}$. of digitoxin and again collected from the same site four to seven days later, during maintenance with $0.2 \mathrm{mg}$. daily dosage. In the remaining two patients, the collection was made only once, following oral digitalization and during maintenance with a daily dose of $0.1 \mathrm{mg}$. digitoxin. All samples of fluid were collected with toluol as preservative, measured, and then extracted immediately or after short periods of storage at $-20^{\circ} \mathrm{C}$.

Duplicate aliquots of $10 \mathrm{ml}$. each were buffered at $\mathrm{pH}$ 8 with $0.1 \mathrm{M}$ phosphate buffer and extracted with $25 \mathrm{ml}$. of methylene chloride by shaking for one hour at room temperature. The flasks were chilled overnight at $4^{\circ} \mathrm{C}$., transferred to $200 \mathrm{ml}$. centrifuge tubes and centrifuged for 30 minutes at $2000 \mathrm{rpm}$. The aqueous layer was aspirated and the protein film then separated from the methylene chloride layer by filtration. The filtrate was evaporated to dryness; a small amount of ethanol was added at the close of the process to drive off all traces of dichloro-

1 Aided by a grant from Eli Lilly and Company. methane. The residue was shaken with $2 \mathrm{ml}$. Tyrode's solution (five times the original concentration) and diluted further if necessary. Bioassay then was performed by the standard embryo duck heart procedure $(2,3)$. The presence of digitoxin was indicated by a more forceful heartbeat followed by the onset of auriculo-ventricular dissociation (2), changes which are specific for digitalis glycosides in contrast with other effects which are induced by various drugs and electrolytes. Standardization was accomplished by the recovery of $1.0,0.05$, and 0.025 micrograms of digitoxin added to the edema fluids of two non-digitalized patients, and from Tyrode's solution containing $5 \mathrm{mg}$. of albumin. Re-extraction of either the aqueous or protein layers did not yield further quantities of digitoxin (or digitoxigenin). In all of the cases where fluid samples without digitalis from any source were available, the extract of the fluid caused no irregularities in the embryo duck heart preparation and served as the biological control of the post-digitalization specimens. The sensitivity of the method permitted the identification of amounts of digitoxin as little as 0.0025 micrograms per cubic centimeter of edema fluid ( $0.25 \mu \mathrm{g}$. per cent).

\section{RESULTS}

As shown in Table I, no digitoxin was found in the edema fluid collected from the subcutaneous tissues of the ankle in the one patient in which such fluid was obtained. Edema fluids collected from the peritoneal cavities of three other patients failed to show detectable amounts of digitoxin; in three others the ascitic fluid was found to contain traces of digitoxin, varying in concentration from 0.002 to 0.02 micrograms per cubic centimeter of fluid. The single specimen of pleural fluid revealed a digitoxin concentration of 0.005 micrograms per $\mathrm{ml}$.

\section{DISCUSSION}

A variable amount of edema fluid is mobilized and excreted by the kidneys when diuresis is induced. For many years it has been assumed that edema fluids of digitalized patients may contain digitalis glycosides (1). This concept has led 
TABLE I

The digitoxin content of edema fluids of digitalized patients

\begin{tabular}{|c|c|c|c|c|c|c|c|}
\hline Patient & Age & Diagnosis & Type of fluid & , & $\begin{array}{l}\text { Volume } \\
\text { of fluid } \\
\text { ( } \mathrm{ml} .)\end{array}$ & $\begin{array}{c}\text { Period of } \\
\text { digitalization } \\
\text { (days) }\end{array}$ & $\begin{array}{c}\text { Digitoxin } \\
\text { content } \\
\mu g . / m l .\end{array}$ \\
\hline $\begin{array}{l}\text { H. C. } \\
\text { S. S. } \\
\text { C. B. } \\
\text { A. L. }\end{array}$ & $\begin{array}{l}47 \\
64 \\
54 \\
64\end{array}$ & $\begin{array}{l}\text { Hepatic cirrhosis } \\
\text { Hepatic cirrhosis } \\
\text { Hepatic cirrhosis } \\
\text { Hepatic cirrhosis } \\
\text { and hepatoma }\end{array}$ & $\begin{array}{l}\text { Ascitic } \\
\text { Ascitic } \\
\text { Ascitic } \\
\text { Ascitic }\end{array}$ & & $\begin{array}{r}500 \\
4700 \\
20 \\
1280\end{array}$ & $\begin{array}{l}5 \\
4 \\
6 \\
4\end{array}$ & $\begin{array}{l}0.020 \\
0.003 \\
\text { none } \\
\text { none }\end{array}$ \\
\hline $\begin{array}{l}\text { J.W. } \\
\text { J.P. }\end{array}$ & $\begin{array}{l}60 \\
72\end{array}$ & $\begin{array}{l}\text { Lymphoma } \\
\text { Hepatic cirrhosis, } \\
\text { atherosclerotic } \\
\text { heart disease }\end{array}$ & $\begin{array}{l}\text { Pleural } \\
\text { Ascitic }\end{array}$ & & $\begin{array}{r}500 \\
2000\end{array}$ & $\begin{array}{l}4 \\
6\end{array}$ & $\begin{array}{l}0.005 \\
0.002\end{array}$ \\
\hline G. R. & 28 & $\begin{array}{l}\text { Rheumatic heart } \\
\text { disease }\end{array}$ & $\begin{array}{l}\text { Subcutaneous } \\
\text { (ankle) }\end{array}$ & & 300 & Chronic* & none \\
\hline J. H. & 54 & $\begin{array}{r}\text { Arteriosclerotic } \\
\text { heart disease }\end{array}$ & Ascitic & & 2400 & Chronic* & none \\
\hline
\end{tabular}

* Received maintenance dose of $0.1 \mathrm{mg}$. daily. All others received $1.2 \mathrm{mg}$., followed by daily dose of $0.2 \mathrm{mg}$.

to the hypothesis that rapid diuresis following the injection of mercurial preparations may introduce excess glycoside into the blood stream and that this "redigitalization" of the already digitalized patient may induce manifestations of digitalis toxicity.

Widespread acceptance of this concept seems based upon two studies. In 1931, Miller and Smith (1) employed the Hatcher cat assay method to study edema fluids obtained from 15 patients and found "digitalis action" in each instance. In 1937, Schnitker and Levine (4) utilized the frog heart to study this problem, finding a "digitalis effect" in 13 of 18 specimens of edema fluid.

The clinical importance of this problem led us to reinvestigate the content of digitoxin in edema fluids, utilizing a microassay technique capable of identifying minute amounts of glycóside. Edema fluids were obtained from peritoneal, pleural, and subcutaneous sites of eight digitalized patients. In six instances, collections were made both before and after digitalization was accomplished. The presence of digitoxin was detected in only four of the eight specimens. In each instance the concentration was less than 0.02 micrograms per ml. of edema fluid. Thus, the maximum content found was of the order of 20 micrograms per liter of fluid. This suggests that the mobilization of even large quantities of edema fluid could not lead to the hypothetical "redigitalization" following rapid diuresis.

Nevertheless, such symptoms as headache, giddiness, weakness, nausea, and even emesis may fol- low marked diuresis, and may be accompanied by cardiac arrhythmias. It seems likely that these manifestations may be due to the marked alteration of water and electrolyte balance induced by rapid diuresis. In this regard there is increasing evidence of the importance of the potassium ion to manifestations of digitalis toxicity $(5,6)$. Of particular interest is the recent report of Lown and associates ( 7 ) of their finding that mercurial-induced diuresis of the digitalized patient can lead to sufficient loss of potassium ion to change the threshold to the toxic action of digitalis, with ensuing manifestations of digitalis toxicity.

\section{SUM MARY}

The content of digitoxin in peritoneal, pleural, and subcutaneous edema fluids was determined by microassay techniques utilizing the embryo duck heart procedure. No digitoxin was detected in specimens removed from four of eight digitalized patients, and only minute amounts were detected in the remaining four specimens. The maximal content of digitoxin was found to be 20 micrograms per liter of fluid.

It was suggested that rapid diuresis of even large quantities of edema fluid cannot lead to "redigitalization" of the already digitalized patient.

\section{REFERENCES}

1. Miller, G. H., and Smith, F. M., The presence of digitalis in edema fluid and its possible clinical significance. J. Clin. Invest., 1931, 10, 666. 
2. Friedman, M., and Bine, R., Jr., Employment of the embryonic duck heart for the detection of minute amounts of a digitalis glycoside (Lanatoside C). Proc. Soc. Exper. Biol. \& Med., 1947, 64, 162.

3. Friedman, M., Byers, S. O., and Bine, R., Jr., Rate of disappearance of digitoxin from the blood of man after its parenteral administration. Federation Proc. 1951, 10, 46.

4. Schnitker, M. A., and Levine, S. A., Presence of digitalis in body fluids of digitalized patients. Arch. Int. Med., 1937, 60, 240.
5. Sampson, J. J., and Anderson, E. M., The treatment of certain cardiac arrhythmias with potassium salts. J. A. M. A., 1932, 99, 2257.

6. Lown, B., Salzberg, H., Enselberg, C. D., and Weston, R. E., Interrelation between potassium metabolism and digitalis toxicity in heart failure. Proc. Soc. Exper. Biol. \& Med., 1951, 76, 797.

7. Lown, B., Wyatt, N. F., Crocker, A. T., Goodale, W. T., and Levine, S. A., Interrelationship of digitalis and potassium in auricular tachycardia with block. Am. Heart J., 1953, 45, 589. 